\title{
Nitrogen Oxides Levels in the Atmosphere of Different Brazilian Urban Centers, by Passive Sampling
}

\author{
Franciele O. C. da Rocha, ${ }^{\oplus a, b}$ Juliana L. Barbosa, ${ }^{b}$ Vânia P. Campos ${ }^{\oplus *, b}$ and \\ Raiane S. Alves ${ }^{b}$ \\ ${ }^{a}$ SENAI-CIMATEC, Av. Orlando Gomes, 1845, Piatã, 41650-010 Salvador-BA, Brazil \\ ${ }^{b}$ Instituto de Química, Universidade Federal da Bahia (UFBA), Campus Ondina, \\ 40170-270 Salvador-BA, Brazil
}

\begin{abstract}
Urban air pollution is still an emerging environmental problem, it causes damage to health and is difficult to be controlled in urban centers. The population of large metropolises is often exposed to concentrations of nitrogen oxides (NOx), mainly due to vehicle emissions. Epidemiological studies claim that exposure to these oxides is strongly correlated with the incidence of different types of cancer. This work evaluated the impact of NOx emissions on the air quality of five Brazilian urban centers, using passive sampling. The $\mathrm{NO} / \mathrm{NO}_{2}$ ratio indicated photochemical aging in the atmosphere of all the cities studied. Although there has been a predominant trend towards decreasing of nitrogen oxides concentrations in many locations, average annual values $>40 \mu \mathrm{g} \mathrm{m}^{-3} \mathrm{NO}_{2}$ have been found, in Brazil as well as other parts of the world, what indicates the need to control air pollution in these areas.
\end{abstract}

Keywords: air quality, nitrogen oxides, passive sampling, urban air pollution, vehicle emission

\section{Introduction}

Air quality in urban areas is a worldwide concern. Several health problems, such as diseases of the respiratory, cardiovascular and cerebrovascular systems until the increase in the number of deaths, have been associated with exposure to pollutants emitted by different sources. ${ }^{1}$ Vehicular traffic contributes significantly to the emission of a series of air pollutants generated by combustion processes in the urban atmosphere.

Nitrogen oxides (NOx) are important pollutants in the chemistry of the atmosphere. The adverse effect of NOx is strengthened by the increase in the primary emissions of nitrogen dioxide $\left(\mathrm{NO}_{2}\right){ }^{2-5}$

$\mathrm{NO}_{2}$, the most toxic of nitrogen oxides, has wellknown effects on human health. It is a strong oxidizing gas, soluble in adipose tissues, lung irritant, and due to its low solubility in aqueous phase it is poorly absorbed in the upper respiratory tract. ${ }^{1}$ Most of the inhaled $\mathrm{NO}_{2}$ reaches the lungs and is deposited primarily in the bronchi, respiratory and terminal bronchioles, with little deposition

*e-mail: vpalmeiracampos@gmail.com

Editors handled this article: Eduardo Carasek and Maria das Graças A. Korn (Associate) in the alveoli. ${ }^{6}$ Although clinical symptoms do not appear immediately, continued exposure to the $\mathrm{NO}_{2}$ concentration levels, normally found in the urban atmosphere, can cause pulmonary morphological changes. ${ }^{7,8}$

Epidemiological studies ${ }^{9-11}$ have shown that long-term NOx exposure, especially $\mathrm{NO}_{2}$, was strongly correlated with the incidence of lung, breast, prostate, bladder, cervical and ovary cancer and infertility.

An estimated 4.2 million premature deaths globally are linked to ambient air pollution, generated mainly by nitrogen dioxide, ozone, sulfur dioxide and particulate matter. ${ }^{12}$ In addition, it contributes to the formation of secondary pollutants such as aerosols and tropospheric ozone, which also generate significant adverse impacts on the population's health. ${ }^{13}$

Due to the effects on human health, fauna and flora, several standards and recommendations on NOx exposure limits in outdoor environments have been established and updated over the last few decades, considering active sampling techniques. The Brazilian National Environmental Council (CONAMA) ${ }^{14}$ recommends up to $60 \mu \mathrm{g} \mathrm{m}^{-3} \mathrm{NO}_{2}$ annually as an air quality standard. The European Union (EU Directive), ${ }^{15}$ the World Health Organization (WHO) ${ }^{16}$ and California Air Resources Board (ARB), ${ }^{17}$ indicate annual 
concentrations of 40,40 and $57 \mu \mathrm{g} \mathrm{m}^{-3} \mathrm{NO}_{2}$ respectively, which are considerably less than those recently updated in the Brazilian legislation $\left(60 \mu \mathrm{g} \mathrm{m}^{-3} \mathrm{NO}_{2}\right)$. The European Union also has a NOx standard $\left(30 \mu \mathrm{g} \mathrm{m}^{-3}\right)$ to protect vegetation, in addition to the health of the population. A bibliographic survey carried out in this work, in databases of Web of Science, Scopus, and Science Direct, showed that about $70 \%$ of the publications between 2011 and 2018 presented annual averages exceeding the European limit for NOx, representing the urban atmosphere of seven different countries (Brazil, China, Spain, France, Italy, South Korea and England). The reported concentration range for the entire survey was 7-180 $\mu \mathrm{g} \mathrm{m}^{-3} \mathrm{NOx}$, in Brazil, in 2016 ${ }^{18}$ and China ${ }^{19}$ (2016-2017), respectively.

Despite recent information and discussions on urban air pollution, $\mathrm{NO}_{2}$ concentrations often exceed air quality standards in urban centers, ${ }^{4,20}$ mainly due to emissions related to vehicular traffic. Several authors ${ }^{4,21-25}$ attributed the non-conformities of $\mathrm{NO}_{2}$ with quality standards, in the air of urban centers to the significant increase in the number of vehicles powered by diesel. This fuel emits less $\mathrm{CO}_{2}$ than gasoline engines, but significantly more NOx.

In 2018, the sale of diesel and biofuel in Brazil increased by 1.6 and $42 \%$, with a total consumption of 55.6 and 19.3 billion liters, respectively. ${ }^{26}$ Sales of common gasoline, however, decreased to 38.3 billion liters (13\%), while the consumption of hydrated ethanol increased. ${ }^{26}$ These values may reflect the atmospheric composition of urban centers, including the increase in NOx levels through the use of diesel and even biodiesel. Many authors ${ }^{5,27-29}$ affirm that the burning of biodiesel increases the emission of NOx by the presence of more oxygen in the molecules of biodiesel mixtures.

The monitoring of atmospheric pollutants allows the quantification of impacts, generating subsidies for decision making, both in urban and environmental management, collaborating in the prevention of health risks and bringing benefits to society. Aiming to contribute to this purpose, this work sought to evaluate the ratio between nitrogen oxides, as a tool to clarify its possible emission sources in Brazilian urban centers. In Brazil it is required by law ${ }^{30}$ that all cities with more than 500 thousand inhabitants and peripheral areas under the direct influence of these regions have an air monitoring station. This is not controlled in the country and compliance with the law is seldom enforced. Of 43 Brazilian cities with more than 500 thousand inhabitants, only 8 monitor the most important conventional pollutants. The main justification for this is the cost of monitoring.

Passive sampling has been shown worldwide as a viable alternative for atmospheric monitoring of gases and vapors with low cost and high spatial resolution. For use in air sampling networks, it has many advantages such as simplicity, low cost, portability, it does not require electricity, maintenance, air flow calibration or trained personnel for operation. ${ }^{31}$ Currently, passive sampling is being used also in official air monitoring networks in developed countries, such as Germany. ${ }^{32}$

The use of a passive sampler can be useful to describe an average value for a prolonged exposure time. The results obtained represent the time-weighted average concentrations of gases or vapors, that is, integrated average concentrations in a given period of exposure time.

The axial tube-type sampler and radial sampler are among the main types of passive samplers. Diffusive samplers having a radial symmetry have the advantage of high sampling rate. They have been very employed for monitoring concentration of common pollutants in the atmosphere. ${ }^{33-36}$ However, this type of diffusive sampler for NOx had not yet been reported until the publication of the work by Motta et al. ${ }^{37}$ in 2018.

The axial tube-type samplers are most frequently used for monitoring a wide variety of pollutants in the atmosphere..$^{31,38-41}$ Many authors ${ }^{18,42-47}$ have applied this type of passive sampler for the determination of NOx, as well outdoors as indoors. The intense use of axial tube-type samplers in comparison to the radial tube-type sampler should occur probably because they are more easily constructed and cheaper and at the same time provide reliable information on pollutant concentrations. The typically low sampling rate of these device types is compensated with a longer exposure time.

$\mathrm{NOx}$, which includes $\mathrm{NO}_{2}$ and $\mathrm{NO}$, is an indicator of vehicular emissions, with important effects on health. Therefore, it is very important to develop monitoring strategies that are also economically viable, easy to operate and usable in different area types.

This work, which applied axial tube-type passive sampler and determines both conventional and unconventional pollutants in five Brazilian urban centers (São Paulo, Belo Horizonte, Rio de Janeiro, Londrina and Salvador) in the period of 2017 and 2018, can serve as a good publicity for Brazilian environmental agencies, as a simple, inexpensive and efficient way to control air pollution. This will facilitate compliance with national legislation, controlling air quality and taking actions aimed at the quality of life of the population.

\section{Experimental}

\section{Study area}

The measurements were performed in five Brazilian urban centers (São Paulo, Belo Horizonte, Rio de Janeiro, 
Londrina and Salvador), as shown in Table 1 and Figure 1. The sampling points represent an external environment with intense vehicular flow. ${ }^{48}$

According to the Koppen and Geiger classification, ${ }^{49}$
São Paulo and Belo Horizonte have humid subtropical climate, characterized by a remarkably dry winter and a very rainy summer, as evidenced by data from the National Meteorological Institute (INMET) for the sampling periods. ${ }^{50}$

Table 1. Geographic location of the sampling points, current and pre-1997 vehicle fleet

\begin{tabular}{|c|c|c|c|c|c|c|c|}
\hline \multirow[b]{2}{*}{ City-state } & \multirow{2}{*}{$\begin{array}{c}\text { No. of } \\
\text { inhabitants }^{51}\end{array}$} & \multicolumn{2}{|c|}{ Coordinate } & \multirow{2}{*}{$\begin{array}{l}\text { Distance from } \\
\text { Salvador }^{\mathrm{a}} / \mathrm{km}\end{array}$} & \multirow[b]{2}{*}{ Sampling point description } & \multirow{2}{*}{$\begin{array}{c}\text { Vehicle } \\
\text { fleet } 2019^{\mathrm{b}} 48\end{array}$} & \multirow{2}{*}{$\begin{array}{c}\text { Vehicle fleet with } \\
\text { manufacturing before } 1997 \\
\text { (without catalyst / \%) }\end{array}$} \\
\hline & & $\mathrm{S} /$ degree & $\mathrm{W} /$ degree & & & & \\
\hline São Paulo-SP & $12,252,023$ & 23.5602107 & 46.7346811 & 1,990 & $\begin{array}{l}\text { external area of the Institute of } \\
\text { Astronomy, Geophysics and } \\
\text { Atmospheric Sciences (IAG), } \\
\text { main University Campus, } \\
\text { distancing ca. } 3 \text { km of intense } \\
\text { vehicular flow pathway }\end{array}$ & $8,341,669$ & $2,365,817(28)$ \\
\hline $\begin{array}{l}\text { Belo } \\
\text { Horizonte-MG }\end{array}$ & $2,512,070$ & 19.8715335 & 43.9551401 & 1,352 & $\begin{array}{l}\text { entrance to the Universidade } \\
\text { Federal de Minas Gerais; } \\
\text { bordering an important highway } \\
\text { and close to landfills }\end{array}$ & $2,088,132$ & $324,111(16)$ \\
\hline $\begin{array}{l}\text { Rio de } \\
\text { Janeiro-RJ }\end{array}$ & $6,718,903$ & 22.8598541 & 433391842 & 1,626 & $\begin{array}{l}\text { terrace of the Technology Center } \\
\text { of the Federal University of Rio } \\
\text { de Janeiro; coastal area with } \\
\text { intense vehicular flow }\end{array}$ & $2,839,512$ & $749,784(26)$ \\
\hline Londrina-PR & 569,733 & 23.3186317 & 511933064 & 2,276 & $\begin{array}{l}\text { avenue distancing ca. } 2 \mathrm{~km} \text { of a } \\
\text { highway with intense vehicular } \\
\text { flow, mainly of heavy vehicles }\end{array}$ & 399,434 & $108,745(27)$ \\
\hline Salvador-BA & $2,872,347$ & 13.000193 & 38.507263 & - & $\begin{array}{l}\text { terrace of the Interdisciplinary } \\
\text { Center for Energy and } \\
\text { environment (CIENAM), coastal } \\
\text { area, close to one of the main } \\
\text { circulation areas of the city; high } \\
\text { afforestation }\end{array}$ & 920,604 & $138,548(15)$ \\
\hline
\end{tabular}

aPlace where the work was coordinated, APs prepared and assembled in kits to be distributed to the other urban centers; ${ }^{\text {b when the use of catalysts became }}$ mandatory in Brazil.

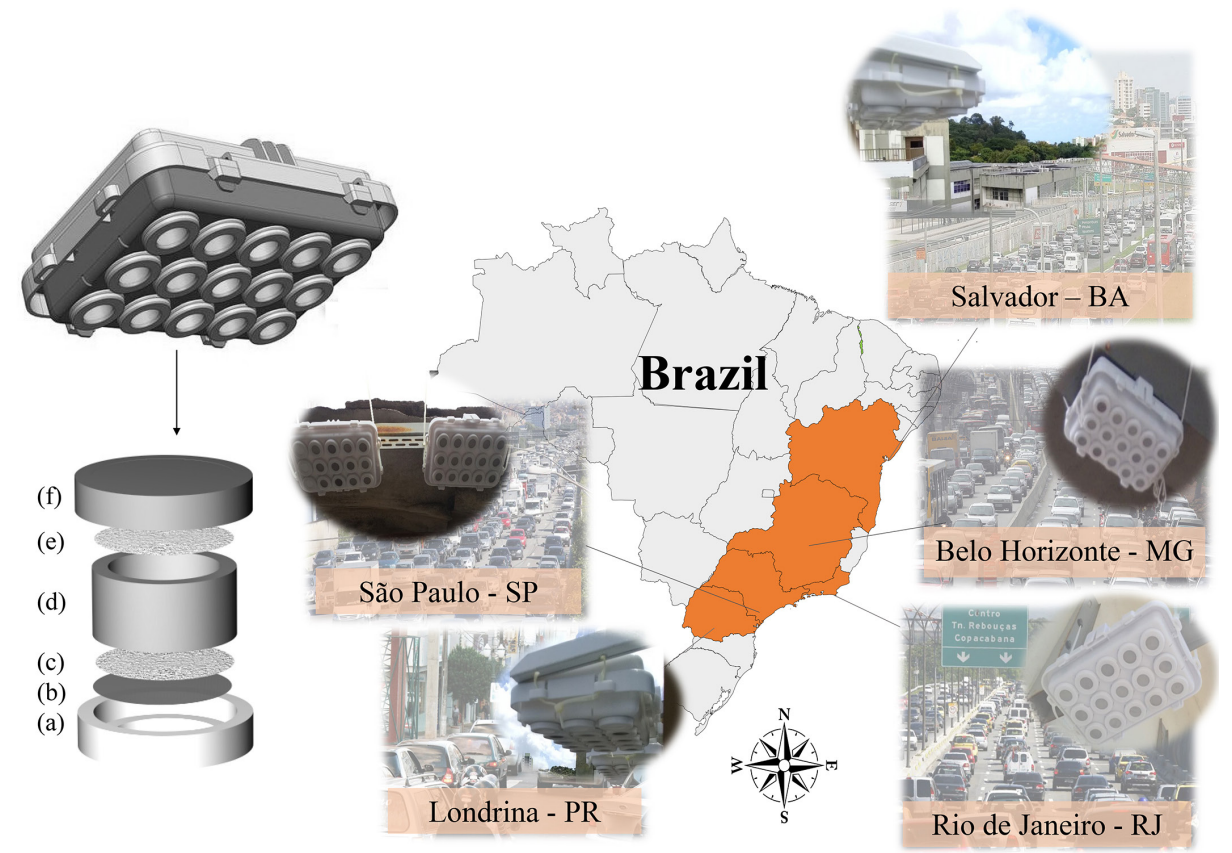

Figure 1. Representation of the location of the sampling stations and description of the passive sampler: (a) air inlet, (b) stainless steel mesh, (c) Teflon membrane, (d) diffusion space, (e) impregnated filter, (f) sampler bottom air inlet. 
In the winter and spring period (June-November) in São Paulo and Belo Horizonte, there is greater atmospheric stability and calm conditions, which is unfavorable to the dispersion of pollutants. Salvador and Rio de Janeiro present little temperature variation, with annual average of 26.5 and $27^{\circ} \mathrm{C}$, respectively, and high solar radiation throughout the year; the dry season is from September to February and rainy season from March to August. ${ }^{50}$ Londrina has more defined seasons and intense rainfall throughout the year.

Table 1 includes information on the vehicle fleet in the five urban centers, besides to the percentage of the vehicle fleet, that were manufactured before 1997, when it became mandatory in Brazil the use of catalysts in vehicles.

The data of Table 1 shows that São Paulo has the largest oldest vehicular fleet (28\% without catalysts), although this data is very close to that one found for Rio de Janeiro and Londrina. Belo Horizonte and Salvador, very different centers about diesel consumption, have practically the same percentage of vehicles without use of catalysts. These observations may reflect a strong correlation between diesel consumption and urban air pollution in these locations, in relation to indicators such as NOx.

\section{Description of the sampling methodology}

Six sampling campaigns were carried out from August/2017 to June/2018. Passive samplers kits were exposed to an average height of $4 \mathrm{~m}$. The choice of this height ensures the safety and integrity of the sampling devices during the entirety of the prolonged exposure period (7 days), allowing them to remain at a place under total control by the collaborating teams in the sampling campaigns at the different urban centers.

For the sampling, was used the Analise $A r \mathrm{kit}^{52}$ (Figure 1), developed and patented nationally by the company EDZA-Planning, Consulting and Informatics, in partnership with a group of researchers from the Universidade Federal da Bahia/Chemistry Institute, Analytical Chemistry Department. The kit contains passive samplers (PS) in triplicate for each gas of interest.

The principle of the passive sampler used is molecular diffusion of the gas through a static air layer. The average atmospheric concentration for the gas fixed in the passive sampler were calculated based on the integration of Fick's first law of diffusion, as a function of the sampled mass and sampling time.

It can be calculated from equation $1:^{.53}$

$\mathrm{C}=\frac{\mathrm{m} \times \mathrm{L}}{\mathrm{D} \times \mathrm{A} \times \mathrm{t}}$

where, m: total mass of the collected gas $(\mu \mathrm{g}), \mathrm{L}$ : diffusion path length (m), D: molecular diffusion coefficient of the gas $\left(\mathrm{m}^{2} \mathrm{~h}^{-1}\right)$, A: cross sectional area of the diffusion path $\left(\mathrm{m}^{2}\right)$, t: passive sampler exposure time $(\mathrm{h})$.

Changing the formof the equation 1 to: $\mathrm{m}=\frac{\mathrm{D} \times \mathrm{A} \times \mathrm{C} \times \mathrm{t}}{\mathrm{L}}$, the sampling rate can be calculated by $\frac{\mathrm{D} \times \mathrm{A}}{\mathrm{L}}$, that is, considering the diffusion coefficient of the sampled gas and the sampler geometry. The rate sampling has the same unit $\left(\mathrm{m}^{3} \mathrm{~h}^{-1}\right)$ of the air flow of the active samplers. The sampling rate can also be calculated considering $\mathrm{m}, \mathrm{C}$ and $\mathrm{t}$ (equation 2): ${ }^{37}$

$\mathrm{SR}\left(\mathrm{m}^{3} \mathrm{~h}^{-1}\right)=\frac{\mathrm{m}(\mu \mathrm{g})}{[\mathrm{C}]\left(\mu \mathrm{g} \mathrm{m}^{-3}\right) \times \mathrm{t}(\mathrm{h})}$

where, SR: sampling rate, $\mathrm{m}$ : total mass of the collected gas $(\mu \mathrm{g}), \mathrm{C}$ : gas sampled concentration $\left(\mu \mathrm{g} \mathrm{m}^{-3}\right)$, t: passive sampler exposure time (h).

The passive samplers (PS) for $\mathrm{NO}_{2}$ and NOx consist of a cylindrical polyethylene body $(12 \mathrm{~mm}$ high and $21 \mathrm{~mm}$ internal diameter) as described by Santana et al. ${ }^{38}$ and Figure 1. After the diffusion space, in the $\mathrm{PS}$ to $\mathrm{NO}_{2}$ there is a cellulose filter impregnated with $200 \mu \mathrm{L} 0.76 \mathrm{~mol} \mathrm{~L}^{-1} \mathrm{TEA}$ (triethanolamine 99\%, Merck, Darmstadt, Germany) and in the PS to NOx, the impregnation solution consists of TEA $0.76 \mathrm{~mol} \mathrm{~L}^{-1}+1.6 \times 10^{-4} \mathrm{~mol} \mathrm{~L}^{-1}$ PTIO (2-phenyl4,4,5,5-tetramethylimidazoline-1-oxyl-3-oxide, Merck, Darmstadt, Germany). In the NOx sampler, the atmospheric $\mathrm{NO}_{2}$ reacts with TEA and is fixed in the impregnated filter; the atmospheric $\mathrm{NO}$, which is oxidized to $\mathrm{NO}_{2}$ in the impregnated filter, by reaction with PTIO. In this way, the NOx concentration $\left(\mathrm{NO}+\mathrm{NO}_{2}\right)$ is determined. The difference between the measured concentrations of NOx and $\mathrm{NO}_{2}$, also allows the indirect determination of $\mathrm{NO}$ concentration.

The choice of reagent to capture $\mathrm{NO}_{2}$ and $\mathrm{NOx}$ in impregnated filters was based on previous studies. ${ }^{31,42,54}$ Field tests were made for both $\mathrm{NO}_{2}$ and NOx, using different concentrations of impregnation reagent and intercalation with other types of samplers.

Although the passive sampling is no longer a novelty, the sampling design used in this work is original, as it uses a kit containing several passive samplers, which makes it possible in a practical way to sample simultaneously different gaseous pollutants. It is a closed PS kit, with covering that serves as protection during outdoors exposure (Figure 1), also making it safe for transporting the kit over long distances. Thus, the kits could be sent by air mail to the different sampling sites, in distant urban centers (Table 1), where they were received, exposed for 7 days and returned to our laboratory for all chemical analyzes. 
The continuous monitoring data were obtained using monitors manufactured by Environnement and calibrated with a dynamic gas calibrator (Environnement, Model EV$3 \mathrm{M}$ ), by chemiluminescence detection.

Backward trajectories of air mass arriving in each city were obtained for each sampling period by using the NOAA HYSPLIT Trajectory Model. ${ }^{55}$

Analytical methodology for the preparation and analysis of the passive samplers

Kits containing passive samplers (PS) were washed twice with 2\% Extran neutral detergent (Merck, Darmstadt, Germany), rinsed with ultrapure water and dried in a clean place at room temperature before assembly. After 7 days of exposure, the kits were again sealed and packaged to be returned to our laboratory for analysis.

The $\mathrm{NO}_{2}$ fixed in the passive samplers was extracted by sonication with $1.5 \mathrm{~mL}$ of ultrapure water, followed by centrifugation at 13,500 rpm for $5 \mathrm{~min}$. Quantification was performed by UV-Vis molecular absorption spectrophotometry, using the Griess-Saltzman method. In this method, the nitrite ion under acidic conditions generates the diazotization of the sulfanilamide (4-aminobenzenesulfonamide) and the product is coupled with the $N$-(1-naphthyl)-ethylenediamine dichloride and measured at $540 \mathrm{~nm}$. For calibration and interpolation of the results, analytical curves in the range of 0.20 to $1.2 \mu \mathrm{g} \mathrm{mL}^{-1}$ $\mathrm{NO}_{2}{ }^{-}$were constructed. In the NOx passive sampler, the NO from the atmosphere is oxidized to $\mathrm{NO}_{2}$ in the impregnated filter due to the presence of the oxidizing agent (PTIO), according to the chemical equation (equation 3 ):

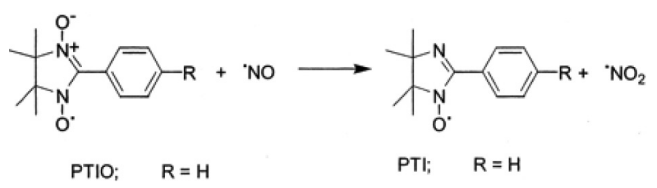

The limit of quantification (LOQ) to determine $\mathrm{NO}_{2}$ was calculated using the equation $4::^{56}$

$\mathrm{LOQ}=\frac{10 \times \mathrm{s}_{\mathrm{b}}}{\mathrm{B}}$

where, $s_{b}$ is the estimate standard deviation of the blanks and $\mathrm{B}$ is the slope of the analytical calibration curve.

\section{Results and Discussion}

\section{Passive sampler validation}

The passive samplers used in this work were validated in the urban area of Salvador-BA, by comparison with two other techniques: active discontinuous sampling and active continuous sampling (continuous monitors for $\mathrm{NO}_{2}$ and NOx). For active discontinuous sampling, were used filters impregnated with the same absorbing solutions used in passive samplers and analyzed by the same method used for the analysis of the pollutants captured in the impregnated filters of the $\mathrm{NO}_{2}$ and $\mathrm{NOx}$ passive samplers.

Two filters in parallel were connected to a pump with an average flow of $65 \mathrm{~L} \mathrm{~h}^{-1}$ for each of them. Different sampling periods were tested: $3,5,7$ and 10 days. The filters used in this active sampling were changed every two hours, after which the compounds of interest were extracted and quantified under the same conditions previously mentioned.

The limit of quantification (LOQ) of the PS, exposed for 7 days, was 0.89 and $0.62 \mu \mathrm{g} \mathrm{m}^{-3}$ for $\mathrm{NO}_{2}$ and $\mathrm{NOx}$, respectively. Passive sampler LOQ was calculated using field blanks to obtain the mass $m$ (equation 1), as well as the diffusion coefficient (D), the cross-sectional area (A) and the total length (L) of the diffusion path related to the passive sampler's geometry. Field blank are filters that are impregnated and mounted on APs, but not exposed to ambient air, prepared and analyzed in the same way as all others.

The accuracy of the PS was assessed at 3.6 and $2.6 \%$ for $\mathrm{NO}_{2}$ and $\mathrm{NOx}$ measures, respectively, considering continuous active sampling (CAS) and 2.3 and $1.3 \%$ considering discontinuous active sampling (DAS). Figures $2 \mathrm{a}$ and $2 \mathrm{~b}$ shows graphically the estimated accuracy for NOx measurements using the PS compared to the two reference methods: CAS and DAS, respectively.

These values meet the recommended limit by the European Union ${ }^{15}$ for passive sampling $( \pm 25 \%)$. The precision of the measurements was 3.1 and $2.7 \%$ for NOx and $\mathrm{NO}_{2}$, respectively. These results, combined with the low limits of quantification, allow us to consider that the optimized samplers are suitable for the atmospheric monitoring of these contaminants in urban areas.

The sampling rate calculated based on 30 simultaneous measurements of $\mathrm{NO}_{2}$ and NOx obtained through 7 days exposure of the passive samplers varied between 0.2123 and 0.2243 and between 0.2388 and $0.2162 \mathrm{~cm}^{3} \mathrm{~min}^{-1}$, respectively.

\section{Concentration of nitrogen oxides in the air}

During the study period (August 2017-June 2018), concentrations in urban centers ranged from 1.4 to $60 \mu \mathrm{g} \mathrm{m}^{-3} \mathrm{NO}_{2}, 0.32$ to $19 \mu \mathrm{g} \mathrm{m}^{-3} \mathrm{NO}$ and 1.9 to $64 \mu \mathrm{g} \mathrm{m}^{-3} \mathrm{NO}_{\mathrm{X}}$. Table 2 shows the individual average values with standard deviation and limit of quantification. 

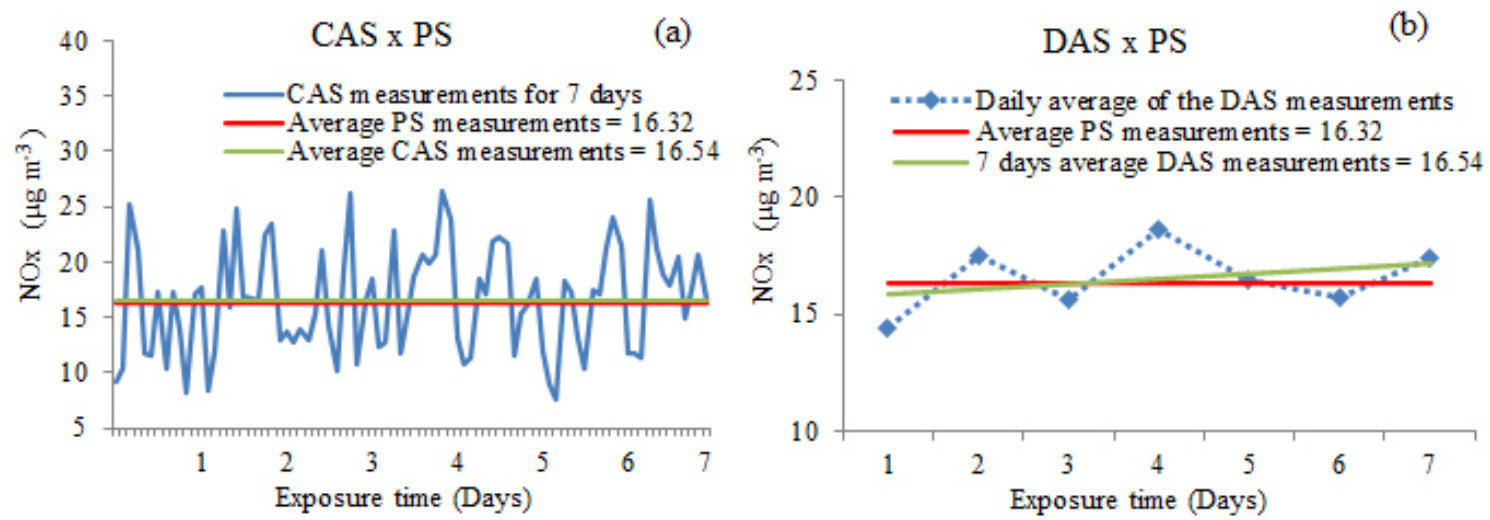

Figure 2. Representation of simultaneous measurements using: (a) passive sampling (PS) $\times$ continuous active sampling (CAS) and (b) passive sampling $(\mathrm{PS}) \times$ active discontinuous sampling (DAS).

During the sampling periods, only in Salvador there was no monitoring of air quality by an official government agency. In São Paulo there was monitoring of $\mathrm{NO}_{2}, \mathrm{NO}$ and NOx and, in Rio de Janeiro and Belo Horizonte, monitoring of $\mathrm{NO}_{2}$.

The annual average concentrations of $\mathrm{NO}_{2}$ in the five Brazilian urban centers included in this study were below the national recommendation of $60 \mu \mathrm{g} \mathrm{m}^{-3} \cdot{ }^{14}$ However, São Paulo presented annual average concentrations NOx higher than recommended by the European Union ${ }^{15}\left(30 \mu \mathrm{g} \mathrm{m}^{-3}\right)$ and Belo Horizonte presented levels close to this limit. The concentration of nitrogen oxides in the atmosphere was presented in the following order: São Paulo > Belo Horizonte $>$ Rio de Janeiro $>$ Londrina $>$ Salvador. These results can indicate a direct correlation with the consumption of diesel fuel, the predominant source of emission of these gases in urban atmospheres, mainly when it is associated with the vehicle fleet and its age (Table 1). This table shows the consumption of this fuel in the cities in study, already considering the final consumer, according to the National Petroleum Agency-Brazil. ${ }^{26}$

The order of diesel consumption between 2017/2018 was exactly the one observed for the levels of nitrogen oxides in the air (São Paulo > Belo Horizonte > Rio de Janeiro $>$ Londrina $>$ Salvador). According to Sao Paulo State Environmental Company (CETESB), ${ }^{57}$ about $64 \%$ of the 78 thousand tons of nitrogen oxides emitted to the São Paulo urban atmosphere in 2017, correspond to vehicle emissions, of which $47 \%$ are from heavy vehicles.

In 2012, the P7 phase of Air Pollution Control Program by Motor Vehicles-Brazil ${ }^{58}$ was implemented in the country, similar to Euro 5-European legislation, ${ }^{59}$ which seeks to reduce and control atmospheric contamination by setting deadlines, limits emissions and technological requirements for motor vehicles, domestic and imported. The new Brazilian legislation seeks $60 \%$ reduction of nitrogen oxides (NOx) in relation to the current phase
(P5, equivalent to Euro $3{ }^{60}$ valid for vehicles produced until December 2011). However, the results obtained in this study show that this reduction is not yet observed and the air quality in relation to these compounds should not change in the short term, since the reduction of NOx emission in vehicles powered by diesel does not attend the P7 phase. It is expected that the implementation of the P8 phase, scheduled for 2022/2023, which will be equivalent to Euro 6, implemented in turn since 2014, will allow reduction of these levels, requiring evolution in fuel and automotive technology.

Figure 3 shows a comparison between the average annual levels of $\mathrm{NO}, \mathrm{NO}_{2}$ and $\mathrm{NOx}$ obtained in this study with recent data of urban atmosphere in other parts of the world and data from official monitoring stations: in Brazil/ São Paulo, ${ }^{61}$ in Germany, ${ }^{32}$ in Portugal, ${ }^{62}$ and in USA. ${ }^{63}$ To report data from the official monitoring stations, two stations were chosen at each location, representing different degrees of vehicular traffic influence.

The figure shows that average annual levels of nitrogen oxides obtained in São Paulo city can be considered similar to the official levels reported by CETESB,${ }^{61}$ for the period of 2018, at the University City monitoring station, which is nearby $(500 \mathrm{~m})$ the sampling point used in this work. In the other Brazilian urban centers, official data on nitrogen oxides in the atmosphere have not been published for the study period. In Brazil, with exception of CETESB, ${ }^{61}$ air quality monitoring in many urban centers is often intermittent, when it is done; therefore, the difficulty of finding data for comparisons with that obtained in this work.

In Figure 3, data from two other stations in urban areas of São Paulo represent extreme concentration levels (higher and lower): Marginal Tietê and Pico do Jaraguá, respectively. Data from the most polluted station in São Paulo are similar to the data from the most polluted stations in Lisbon and Berlin, also reported in this figure. It is noteworthy that the stations chosen to represent Berlin's 
Table 2. Average $\mathrm{NO}_{2}, \mathrm{NO}$ and NOx concentrations in Brazilian urban centers, 2017-2018

\begin{tabular}{|c|c|c|c|c|}
\hline \multirow{2}{*}{ Site } & \multirow{2}{*}{ Sampling } & \multicolumn{3}{|c|}{ Concentration $\pm \mathrm{SD} /\left(\mu \mathrm{g} \mathrm{m}^{-3}\right)$} \\
\hline & & $\mathrm{NO}_{2}$ & NO & NOx \\
\hline \multirow{9}{*}{ São Paulo-SP } & S1 & $26 \pm 1.1$ & $2.4 \pm 0.94$ & $28 \pm 2.0$ \\
\hline & S2 & $10 \pm 1.3$ & $1.6 \pm 1.1$ & $12 \pm 0.23$ \\
\hline & S3 & $60 \pm 0.24$ & $4.1 \pm 2.6$ & $64 \pm 2.7$ \\
\hline & S4 & $28 \pm 0.21$ & $7.2 \pm 1.4$ & $35 \pm 1.3$ \\
\hline & S5 & $44 \pm 6.2$ & $12 \pm 5.9$ & $57 \pm 0.35$ \\
\hline & S6 & $13 \pm 0.30$ & $19 \pm 0.64$ & $33 \pm 0.54$ \\
\hline & $\overline{\mathrm{X}}$ annual & 30 & 7.8 & 38 \\
\hline & $\min$ & 10 & 1.6 & 12 \\
\hline & $\max$ & 60 & 19 & 64 \\
\hline \multirow{9}{*}{$\begin{array}{l}\text { Belo } \\
\text { Horizonte-MG }\end{array}$} & S1 & $26 \pm 0.60$ & $1.3 \pm 0.65$ & $27 \pm 0.10$ \\
\hline & S2 & $14 \pm 1.7$ & $4.9 \pm 2.5$ & $19 \pm 0.97$ \\
\hline & S3 & $27 \pm 0.26$ & $2.2 \pm 1.1$ & $29 \pm 1.0$ \\
\hline & S4 & $33 \pm 3,0$ & $3.8 \pm 2.8$ & $37 \pm 0.82$ \\
\hline & S5 & $17 \pm 0.13$ & $1.4 \pm 0.96$ & $19 \pm 1.1$ \\
\hline & S6 & $23 \pm 1.6$ & $3.9 \pm 2.2$ & $27 \pm 1.1$ \\
\hline & $\overline{\mathrm{X}}$ annual & 23 & 2.9 & 26 \\
\hline & $\min$ & 14 & 1.3 & 19 \\
\hline & $\max$ & 33 & 4.9 & 37 \\
\hline \multirow{9}{*}{$\begin{array}{l}\text { Rio de } \\
\text { Janeiro-RJ }\end{array}$} & S1 & ND & ND & ND \\
\hline & S2 & $6.8 \pm 0.42$ & $2.0 \pm 2.8$ & $8.8 \pm 2.9$ \\
\hline & S3 & $14 \pm 0.81$ & $5.9 \pm 1.2$ & $20 \pm 0.35$ \\
\hline & S4 & ND & ND & ND \\
\hline & S5 & $16 \pm 0.14$ & $0.82 \pm 0.66$ & $17 \pm 0.67$ \\
\hline & S6 & $17 \pm 1.3$ & $5.1 \pm 2.1$ & $23 \pm 2.0$ \\
\hline & $\overline{\mathrm{X}}$ annual & 13 & 3.5 & 17 \\
\hline & $\min$ & 6.8 & 0.82 & 8.8 \\
\hline & $\max$ & 17 & 5.9 & 23 \\
\hline \multirow{9}{*}{ Londrina-PR } & $\mathrm{S} 1$ & $7.9 \pm 1.8$ & $3.4 \pm 2.0$ & $11 \pm 0.65$ \\
\hline & S2 & $3.7 \pm 0.18$ & $0.32 \pm 0.18$ & $4.0 \pm 0.25$ \\
\hline & S3 & $19 \pm 1.0$ & $2.3 \pm 1.1$ & $21 \pm 1.1$ \\
\hline & S4 & $7.2 \pm 2.2$ & $9.5 \pm 2.1$ & $17 \pm 0.10$ \\
\hline & S5 & ND & ND & ND \\
\hline & S6 & $5.3 \pm 0.13$ & $0.7 \pm 0.08$ & $6.0 \pm 0.16$ \\
\hline & $\overline{\mathrm{X}}$ annual & 8.6 & 3.3 & 12 \\
\hline & $\min$ & 3.7 & 0.32 & 4.0 \\
\hline & $\max$ & 19 & 9.5 & 21 \\
\hline \multirow{9}{*}{ Salvador-BA } & S1 & $6.2 \pm 0.75$ & $0.58 \pm 0.35$ & $6.8 \pm 1.1$ \\
\hline & S2 & $7.8 \pm 1.0$ & $0.43 \pm 0.48$ & $8.3 \pm 1.5$ \\
\hline & S3 & $7.8 \pm 0.8$ & $2.8 \pm 1.1$ & $11 \pm 1.1$ \\
\hline & S4 & $2.7 \pm 0.39$ & $0.62 \pm 0.43$ & $3.3 \pm 0.70$ \\
\hline & S5 & $1.4 \pm 0.35$ & $0.52 \pm 0.17$ & $1.9 \pm 0.19$ \\
\hline & S6 & $5.3 \pm 0.15$ & $4.9 \pm 0.14$ & $10 \pm 0.29$ \\
\hline & $\overline{\mathrm{X}}$ annual & 5.2 & 1.6 & 6.8 \\
\hline & $\min$ & 1.4 & 0.43 & 1.9 \\
\hline & $\max$ & 7.8 & 4.9 & 11 \\
\hline
\end{tabular}

\section{Limit of}

quantification /

0.89

0.62

$\left.(\mu \mathrm{g} \mathrm{m})^{-3}\right)$

SD: standard deviation of mean; S: sampling; ND: not detected; S1: August 02-09 2017; S2: September 21-28, 2017; S3: November 14-21, 2017; S4: January 25-February 01. 2018; S5: March 23-30. 2018 and S6: June 15-22. 2018; $\overline{\mathrm{X}}$ : mean; min: minimum; max: maximum. atmosphere use passive samplers, as well as this work. The nitrogen oxide data reported by the USEPA (United States Environmental Protection Agency) ${ }^{63}$ refer only to $\mathrm{NO}_{2}$ concentrations and it can be seen that the annual average (2018) of these concentrations in the least polluted point of New York is among the concentrations found in this work for the period of 2017-2018 in Belo Horizonte and Rio de Janeiro.

Among all the annual NOx averages determined in this work, only in São Paulo the limit of $30 \mu \mathrm{g} \mathrm{m}^{-3}$ recommended by the European Union ${ }^{15}$ for the protection of vegetation was exceeded. These also occurred in the official monitoring stations in Lisbon and Berlin (Figure 3). One reason to consider this critical value important in urban areas is to extend the concern to green spaces in cities used as recreational facilities, which is also linked to human health. ${ }^{32}$ The figure shows that this also occurred in relation to $\mathrm{NO}_{2}$ concentrations, whose annual limit of $40 \mu \mathrm{g} \mathrm{m}^{-3}$, established by WHO, ${ }^{16}$ for the protection of human health was exceeded at the official stations with the greatest influence of vehicular traffic: São Paulo (Marginal Tietê, $57 \mu \mathrm{g} \mathrm{m}^{-3}$ ), Lisbon (Av da Liberdade, $60 \mu \mathrm{g} \mathrm{m}^{-3}$ ) and Berlin (MS525, $59 \mu^{-3} \mathrm{~m}^{-3}$ ). Among the sampling points used in this work, the $\mathrm{NO}_{2}$ concentration was not exceeded in any of them, reaching a maximum annual average of $30 \mathrm{\mu g} \mathrm{m}^{-3}$ in São Paulo, a value similar to the average found by the official CETESB station at its University station City, near the sampling point of this work in that city.

Regarding the concentration levels of nitrogen oxides in other places in the world, it can be seen in Figure 3 that, in general, the highest data refer to China (Wuhan and Nanjing), ${ }^{19,64}$ followed by Korea (Seoul) ${ }^{69}$ Iran (Ahvaz) ${ }^{65}$ and European countries: Spain (Barcelona), ${ }^{75}$ Italy (Turin and Rome) and France (Paris)..$^{72}$ The atmospheric concentrations of $\mathrm{NO}, \mathrm{NO}_{2}$ and $\mathrm{NOx}$ found in this work in the five Brazilian urban centers are lower, mainly in places with high ventilation from the sea, such as Rio de Janeiro and Salvador. For this last location, data published in 2016 for the 2014-2015 period are also presented in Figure 3, this time at a sample point with influence of intense vehicular traffic, where the limit for NOx has been exceeded. Although some authors ${ }^{76,77}$ state that atmospheric concentrations of nitrogen oxides are decreasing over the years, in Figure 3 appears that the $\mathrm{NO}_{2}$ concentrations do not decrease over time, mainly in China.

Schneider et $a l .{ }^{76}$ studied trends of tropospheric nitrogen dioxide over large urban agglomerations for the period August 2002 to March 2012 and the results indicated distinct spatial patterns in $\mathrm{NO}_{2}$ trends. Decreasing $\mathrm{NO}_{2}$ atmospheric concentration levels have been observed in North America, Europe, Australia and Japan, while 


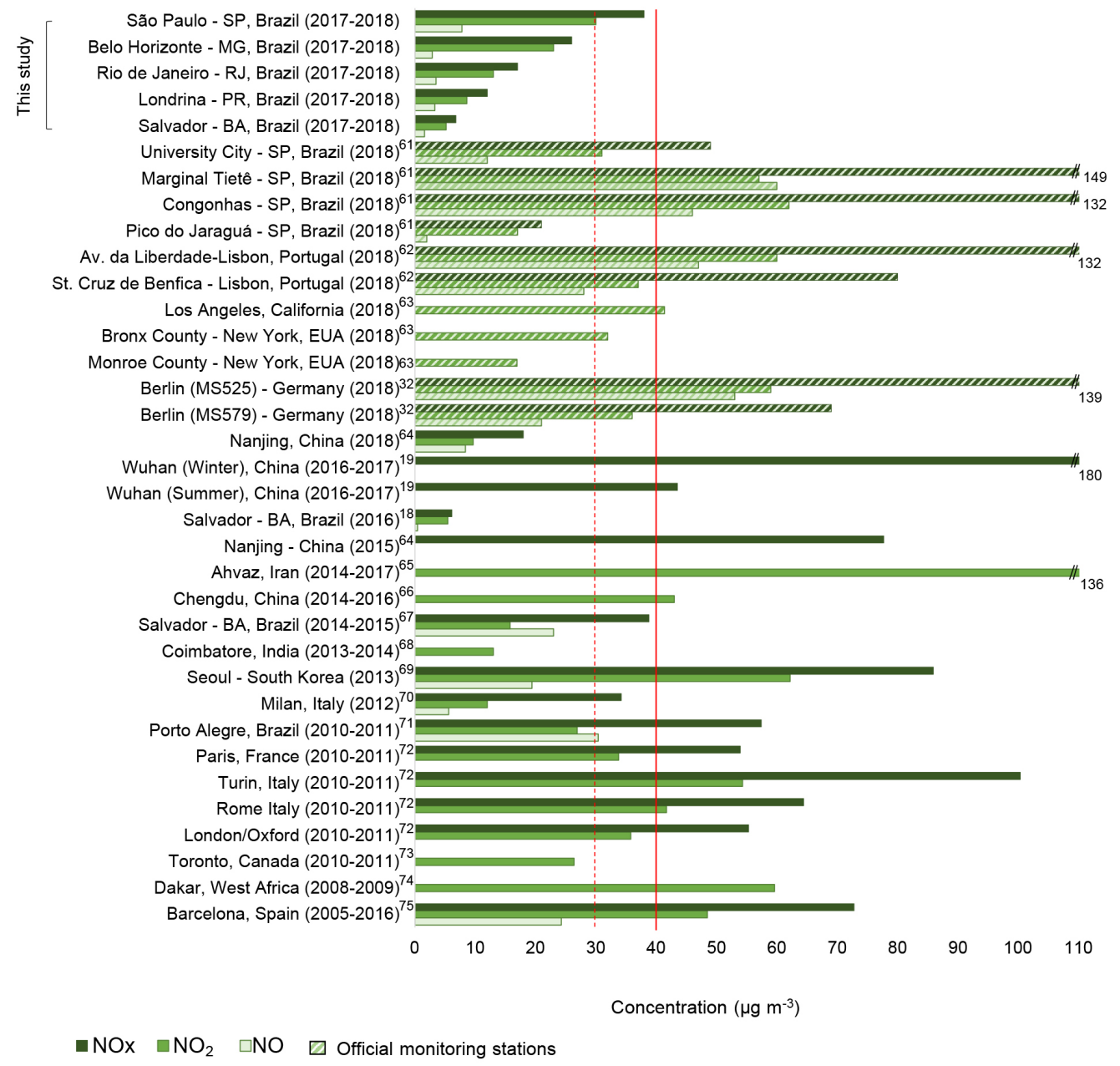

- - - Critical levels for the protection of vegetation for NOx (EU-Directive, 2008)

- Limit values for the protection of human health for $\mathrm{NO}_{2}(\mathrm{WHO}, 2005)$

Figure 3. Comparison between average annual concentrations obtained in this study with data of urban atmosphere in other parts of the world and data reported by official monitoring stations..$^{18,19,32,61-75}$

moderately to rapidly increasing trends have been observed throughout China, South Asia, most of Africa and South America.

The occurrence of variations in the trend of atmospheric levels of a pollutant can be caused by different conditions in certain periods or locations. For example, a decrease in $\mathrm{NO}_{2}$ pollution over a given period may be due to the increased use of catalytic converters to regulate emissions from vehicle engines. This situation may partially reverse due to the increase in the number of vehicles, which may reflect an only slow annual reduction in $\mathrm{NO}_{2}$ levels. On the other hand, the increase in these levels in a given annual period can also be attributed to other causes, for example, unfavorable meteorological situation to the dispersion of the pollutants. ${ }^{32}$

Despite the largest reduction of NOx emissions since 1990 , probably as a reflex of the sustained efforts to improve air quality, ${ }^{77}$ concentrations of $\mathrm{NO}_{2}$ in recent years have not kept pace with reducing emissions. Average annual values above $40 \mu \mathrm{g} \mathrm{m}^{-3} \mathrm{NO}_{2}$ still have been measured in official monitoring stations $\mathrm{s}^{32,61-63}$ and recent works ${ }^{19,43,64,69,75}$ indicate that the concentrations of nitrogen oxides are still an alert to the need to control air pollution in urban areas influenced by vehicular traffic.

Influence of the seasonality (dry or rainy season) on the spatial distribution of nitrogen oxide concentrations in the Brazilian urban centers atmosphere

The concentration of pollutants in the atmosphere is directly influenced by the distribution and intensity of atmospheric emissions, topography and prevailing weather conditions.

The results obtained in this study were correlated with meteorological parameters: precipitation, temperature, wind speed and solar radiation (Figure 4). 

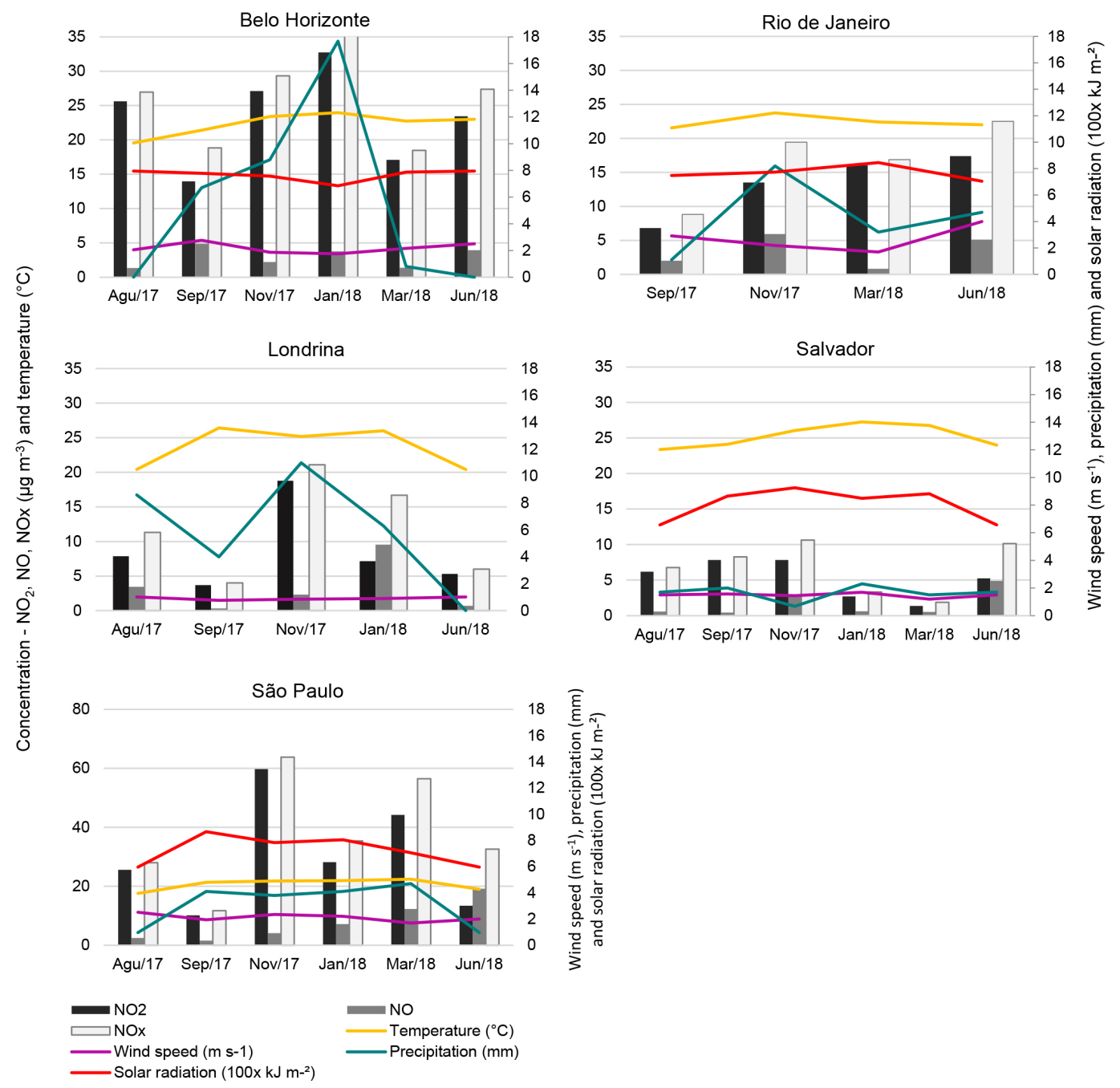

Figure 4. Variation of the average nitrogen oxides concentrations $\left(\mu \mathrm{g} \mathrm{m}^{-3}\right)$ depending on meteorological parameters. Meteorological data source: INMET. ${ }^{50}$

Figure 4 shows that the studied urban centers have different dry and wet periods, what reflects in the distribution pattern of the atmospheric concentrations, depending on the meteorological parameters characteristic of each period, in each center. Salvador and Rio de Janeiro presented lower levels of $\mathrm{NO}_{2}$ in the rainy season (March-August), when compared to the dry season (September-February), as expected due to the wet deposition of pollutants. Associated with that, a study of reverse trajectories of air masses, model NOAA HYSPLIT, ${ }^{55}$ shows that these two cities, during the sampling periods, were predominantly influenced by air masses coming from the ocean, supposedly cleaner than the air masses that pass through continental anthropized areas ${ }^{63}$ (Figure 5). However, in São Paulo and Belo Horizonte, despite the fact that precipitation in most of the time, in 2017, was higher than the climatological averages, ${ }^{61}$ these conditions were not sufficient to avoid periods of high concentration of nitrogen oxides, especially in August, November and December, indicating, in this case, an intense and continuous source of $\mathrm{NO}_{2}$, that seems overcome the effect of wet deposition.

The data were also used in a Pearson's correlation study and the resulting correlation matrix between NO, $\mathrm{NO}_{2}$ and NOx concentrations and meteorological data confirmed most of the observations that can be made by analyzing Figure 3 . Additionally, the matrix shows that there is a moderate to strong correlation between $\mathrm{NO}_{2}$ and NOx in the five locations, which would be obvious, since the sum of the concentration levels of these compounds corresponds to NOx in the atmosphere. However, $\mathrm{NO}_{2}$ and NO did not correlate with each other, indicating equilibrium between the oxidation of $\mathrm{NO}$ to $\mathrm{NO}_{2}$ and the photolysis rate of $\mathrm{NO}_{2}$, resulting in a stationary process depending on meteorological conditions.

Despite a small variation in the average temperature between the periods and studied locations, it is also observed that the highest average concentrations of nitrogen oxides were reported in warmer months and with 
(a) Backward trajectory ending at 1000 UTC 27 Sep 17 GDAS Meteorological Data

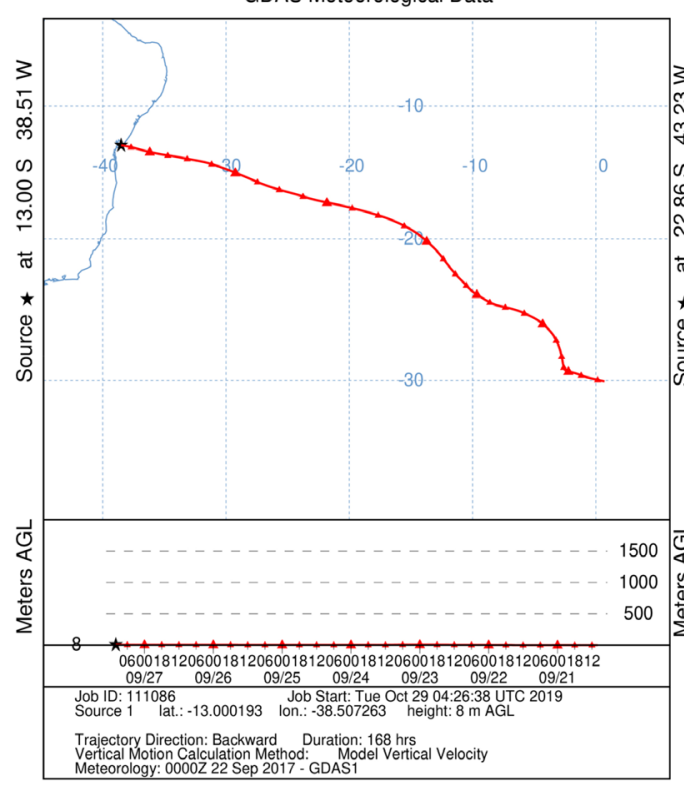

(b) NOAA HYSPLIT MODEL Backward trajectory ending at 1000 UTC 21 Nov 17 GDAS Meteorological Data

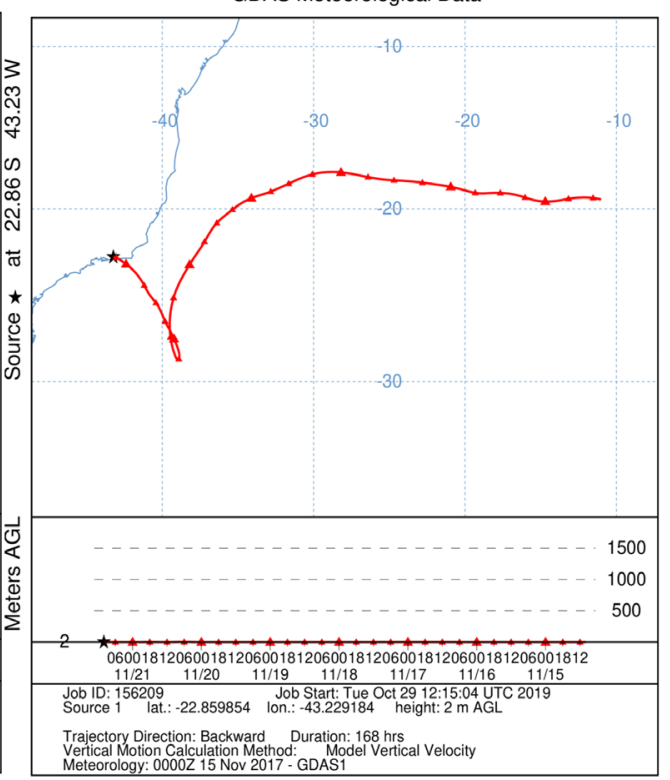

Figure 5. Typical backward trajectories of air masses arriving in Salvador-BA (a) and Rio de Janeiro-RJ (b). Data source: NOAA. ${ }^{55}$

a higher incidence of solar radiation. Wind speed was not a significant parameter to justify more intense dispersions of these pollutants in the sampling periods. Winds were relatively light: $1.7-2.3 \mathrm{~m} \mathrm{~s}^{-1}$ in São Paulo, $1.7-2.8 \mathrm{~m} \mathrm{~s}^{-1}$ in Belo Horizonte, $1.7-4 \mathrm{~m} \mathrm{~s}^{-1}$ in Rio de Janeiro, $0.8-1 \mathrm{~m} \mathrm{~s}^{-1}$ in Londrina, and 1.2-1.7 $\mathrm{m} \mathrm{s}^{-1}$ in Salvador.

The distribution of individual atmospheric concentrations of the nitrogen oxides is represented by the amplitude of the boxplot diagram in Figure 6, in the urban center.

The analysis of Figure 6 shows the existence of a substantial spatial variability for the concentrations of $\mathrm{NO}_{2}, \mathrm{NO}$ and NOx. The contrast of individual averages and median concentrations was small for Salvador, Londrina and Rio de Janeiro. As well as the contrast of median concentrations. The greatest spatial variation of $\mathrm{NO}_{2}$ and NOx concentrations was found in the largest cities included in this study, São Paulo and Belo Horizonte. The average range for $\mathrm{NO}_{2}$ (difference between the highest and lowest mean of each sample) was $52.1 \mu \mathrm{g} \mathrm{m}^{-3}$ in São Paulo.

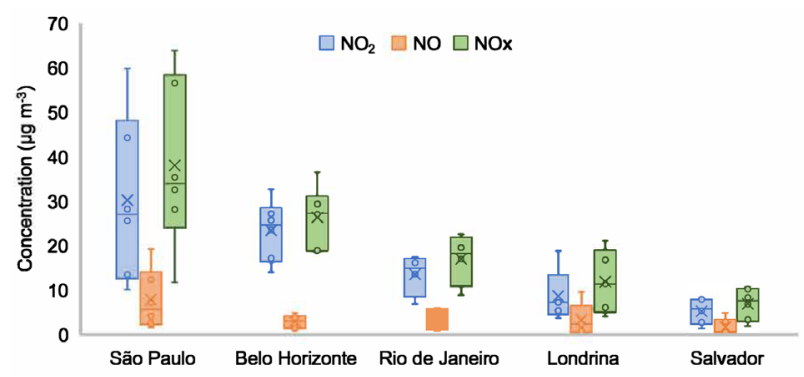

Figure 6. Boxplot diagram for the distribution of the average $\mathrm{NO}_{2}$, $\mathrm{NO}$ and NOx concentrations.

\section{Dispersion of pollution and photochemical aging}

Several factors can interfere in the levels of pollutants present in an atmosphere. In addition to dilution and dispersion, the chemical and photochemical transformations also alter the concentrations of these pollutants, generating a different atmospheric composition with a degree of photochemical age in relation to the components of fresh emissions. It follows that a difference between current composition in the atmosphere and the composition in the original emission at the source, measures photochemical aging. ${ }^{43}$

Nitrogen oxide (NO) dominates vehicle emissions in terms of nitrogen oxides $;^{78}$ however, it is also oxidized at an accelerated rate by ozone in the atmosphere forming secondary $\mathrm{NO}_{2}$. The $\mathrm{NO} / \mathrm{NO}_{2}$ ratio refers to the photochemical age of the pollution; low $\mathrm{NO} / \mathrm{NO}_{2}$ ratios $(\leq 0.5)$ suggest photochemical aging for these compounds in the air, considering that they reach the photochemical steady state (PS), where the $\mathrm{NO}_{2}$ formation and decomposition are balanced. Since NOx is considered the sum of $\mathrm{NO}$ and $\mathrm{NO}_{2}$, high $\mathrm{NO}_{2} / \mathrm{NOx}$ ratios $(\geq 0.9)$ indicate an intense transformation of $\mathrm{NO}$ into $\mathrm{NO}_{2}$ through reactions with ozone, inferring about the influence of traffic in this environment. ${ }^{43}$ Figures $7 \mathrm{a}$ and $7 \mathrm{~b}$ shows the NO/ $\mathrm{NO}_{2}$ and $\mathrm{NO}_{2} / \mathrm{NOx}$ ratios as a function of NOx levels for the five urban centers studied.

In Figures $7 \mathrm{a}$ and $7 \mathrm{~b}$ it is possible to observe the formation of two groups with distinct markings. In Figure $7 \mathrm{a}$, the first group represents $85 \%$ of the data and 
(a)

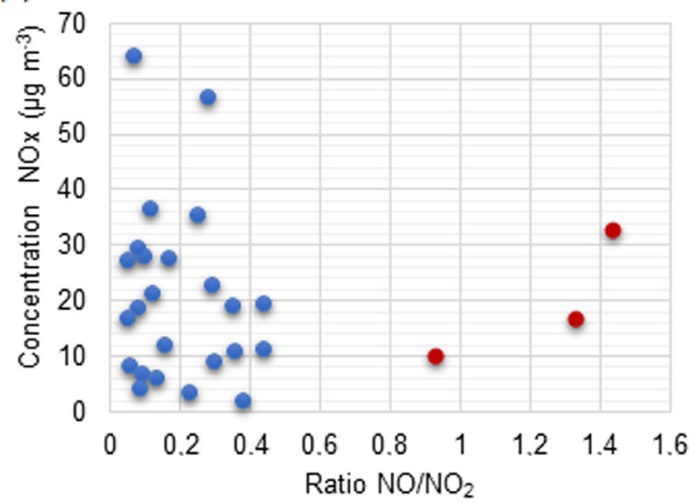

(b)

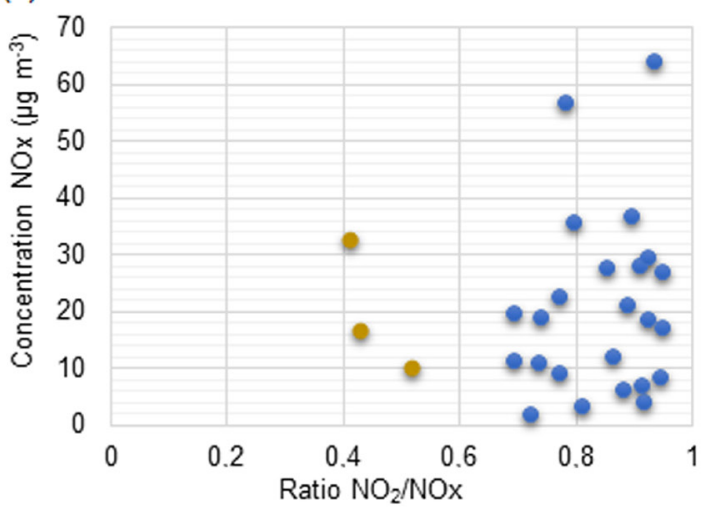

Figure 7. $\mathrm{NO} / \mathrm{NO}_{2}(\mathrm{a}), \mathrm{NO}_{2} / \mathrm{NOx}$ (b) ratios as function of $\mathrm{NOx}$ and $\mathrm{NO}_{2}$ levels in the atmosphere of the studied urban centers.

is characterized by the $\mathrm{NO} / \mathrm{NO}_{2}$ ratio below 0.50 , inferring that the atmosphere of the studied Brazilian urban centers has photochemical aging of nitrogen oxides. The second group, with only 3 ratios $>0.90$, demonstrates for the specific period, significant influence of fresh emissions due to possible intensive sources nearby. These ratios correspond to Salvador in June/2018 (rainy season), São Paulo in June/2018 (dry season, winter) and Londrina in March/2018 (rainy season). Although the locations present different levels of precipitation in the same sampling period, these ratios occurred in periods with lower index of solar radiation, which does not favor the conversion of $\mathrm{NO}$ to $\mathrm{NO}_{2}$, justifying the higher $\mathrm{NO} / \mathrm{NO}_{2}$ ratios.

Figure $7 \mathrm{~b}$ shows that, in general, Brazilian urban centers present high $\mathrm{NO}_{2} / \mathrm{NOx}$ ratios, representing intense primary $\mathrm{NO}_{2}$ emissions and favoring the chemistry of the atmosphere in the formation of secondary $\mathrm{NO}_{2}$. ANP data ${ }^{26}$ show an increase in the number of vehicles powered by diesel, and consequently, an increase in diesel consumption in recent years (Table 1), inferring that the results presented may be more associated with the increase in the contribution of direct emissions of $\mathrm{NO}_{2}$ for the total NOx levels.

In agreement with this study, other recent studies s, $21,43,72,79^{2}$ also report evidence of increased NOx emission rates due to an increase in primary $\mathrm{NO}_{2}$ emissions compared to the ozone/NOx equilibrium in urban areas. This increase is also attributed to the more intense use of diesel-powered vehicles, which emit a greater fraction of $\mathrm{NO}_{2}$ compared to gasoline-powered vehicles. ${ }^{5,72,79}$

In addition, Williams and Carslaw ${ }^{2}$ and Mavroidis and Chaloulakou, ${ }^{21}$ stated that oxidation catalysts implemented to reduce the emission of particulate matter by diesel powered vehicles can also contribute to increase the fraction of primary $\mathrm{NO}_{2}$ in NOx. In diesel engines equipped with catalysts, primary $\mathrm{NO}_{2}$ fractions of about 40 to $50 \%$ are reported in ratio $\mathrm{NO}_{2} / \mathrm{NOx} .^{80}$
Thus, the rations $\mathrm{NO}_{2} / \mathrm{NOx}$ demonstrate that emissions from diesel vehicles have a greater influence on the concentrations of nitrogen oxides in the urban atmosphere of the Brazilian studied cities, indicating an alert for the current situation of emissions and control of nitrogen oxides as pollutants.

\section{Conclusions}

The maximum atmospheric concentrations were obtained in São Paulo: 60, 19 and $64 \mu \mathrm{g} \mathrm{m}^{-3}$ for $\mathrm{NO}_{2}$, $\mathrm{NO}$ and NOx respectively. All studied urban centers had annual average of $\mathrm{NO}_{2}$ concentrations below the national recommendation by CONAMA 491/2018 $\left(60 \mu \mathrm{g} \mathrm{m}^{-3}\right)$. However, São Paulo and Belo Horizonte showed NOx levels higher than that recommended since 2008 by the EU-Directive $\left(30 \mu \mathrm{g} \mathrm{m}^{-3}\right)$ to protect the vegetation.

The evaluation of atmospheric concentrations as a function of the seasonality (dry and rainy season) and considering the meteorological parameters temperature, precipitation and wind speed showed that precipitation was the most influential parameter in the atmospheric concentration of those compounds and indicated also that, São Paulo and Belo Horizonte have a continuous source of $\mathrm{NO}_{2}$, whose influence on atmospheric concentrations is significantly greater than the influence of wet deposition. In addition, as expected, average concentrations of nitrogen oxides are reported in warmer months and with a higher incidence of solar radiation.

The low $\mathrm{NO} / \mathrm{NO}_{2}$ ratios showed that the urban atmosphere of the studied cities has a photochemical aging in relation to nitrogen oxides. Emissions from diesel vehicles have a greater influence on the concentrations of nitrogen oxides in the urban atmosphere of those cities, suggesting that reductions of NOx in the emissions from diesel vehicles can substantially reduce average concentrations of $\mathrm{NO}_{2}$, being up to the agencies 
responsible for controlling vehicle emissions to take these steps.

The results obtained in this work show that there are still no significant improvements in PROCONVE's P7 phase in terms of vehicular NOx emissions and point to the need to comply with the mandatory legislated in Brazil, in relation to the monitoring of these pollutants, which is still poorly fulfilled and supervised in the country.

Use of passive sampling indicates an alternative to be used especially in underdeveloped and developing countries to control air pollution and ensure greater protection of the population's health.

\section{Acknowledgments}

The authors would like to thank the Agência Nacional de Desenvolvimento Científico e Tecnológico (CNPq); Instituto Nacional de Ciência e Tecnologia-Energia e Ambiente (INCT-E\&A); Fundação de Amparo à Pesquisa do Estado da Bahia (FAPESB); Programa Institucional de Bolsas de Iniciação Científica (PIBIC); CETREL for the availability of continuous monitoring data; Professors Pérola Vasconcellos (USP-SP), Zenilda Cardeal (UFMGMG), Graciella Arbilla (UFRJ-RJ) and Cristina Solci (UEL-PR), for collaboration on sampling campaigns. FOCR thanks CNPq for her current fellowship (No. 150364/2019-9).

\section{Author Contributions}

FOCR was responsible for conceptualization, data collection, analysis, and writing original draft preparation; JLB for data collection and analysis; VPC for supervision and writing review and editing; RSA for data collection and analysis. All authors reviewed the manuscript.

\section{References}

1. World Health Organization (WHO); Review of Evidence on Health Aspects of Air Pollution- REVIHAAP; Regional Office for Europe of the WHO, 2013, available at http://www.euro. who.int/_data/assets/pdf_file/0020/182432/e96762-final.pdf, accessed in September 2021

2. Williams, M. L.; Carslaw, D. C.; Atmos. Environ. 2011, 45, 3911.

3. Kurtenbach, R.; Kleffmann, J.; Niedojadlo, A.; Wiesen, P.; Environ. Sci. Eur. 2012, 24, 21.

4. Degraeuwe, B.; Thunis, P.; Clappier, A.; Weiss, M.; Lefebvre, W.; Janssen, S.; Vranckx, S.; Atmos. Environ. 2016, 126, 218.

5. O’Driscoll, R.; ApSimon, H. M.; Oxley, T.; Molden, N.; Stettler, M. E. J.; Thiyagarajah, A.; Atmos. Environ. 2016, 145, 81.
6. EPA United States Environmental Protection Agency; Nitrogen Dioxide $\left(\mathrm{NO}_{2}\right)$ Pollution, available at https://www.epa.gov/ no2-pollution/basic-information-about-no2\#Effects, accessed in September 2021.

7. Kosaka, H.; Uozumi, M.; Tyuma, I.; Free Radicals Biol. Med. 1989, 7, 653 .

8. Mckee, D. J.; Rodriguez, R. M.; Water, Air, Soil Pollut. 1993, $67,11$.

9. Al-Ahmadi, K.; Al-Zahrani, A.; Int. J. Environ. Res. Public Health 2013, 10, 5844.

10. Heinrich, J.; Thiering, E.; Rzehak, P.; Krämer, U.; Hochadel, M.; Rauchfuss, K. M.; Gehring, U.; Wichmann, H.; Occup. Environ. Med. 2013, 70, 179.

11. Hystad, P.; Demers, P. A.; Johnson, K. C.; Carpiano, R. M.; Brauer, M.; Epidemiology 2013, 24, 762.

12. World Health Organization (WHO); Ambient Air Pollution: Health impacts, available at https://www.who.int/airpollution/ ambient/health-impacts/en/, accessed in September 2021.

13. Finlayson-Pitts, B. J.; Faraday Discuss. 2017, 200, 11.

14. Conselho Nacional do Meio Ambiente (CONAMA); Resolução No. 491, de 19 de novembro de 2018, Dispõe sobre Padrões de Qualidade do Ar; Diário Oficial da União (DOU), Brasília, No. 223, de 21/11/2018, p. 155 , available at https://www. in.gov.br/materia/-/asset_publisher/Kujrw0TZC2Mb/content/ id/51058895, accessed in September 2021.

15. European Union (EU); Directive 2008/50/EC on Ambient Air Quality and Cleaner Air for Europe; Official Journal of the European Union, 2008, available at https://eur-lex.europa.eu/ legal-content/EN/TXT/PDF/?uri=CELEX:32008L0050\&from =en, accessed in September 2021.

16. World Health Organization (WHO); Air Quality Guidelines-2005, available at https://www.euro.who.int/__data/assets/pdf_ file/0005/78638/E90038.pdf, accessed in September 2021.

17. California Air Resources Board (ARB); Review of the California Ambient Air Quality Standard for Nitrogen Dioxide: Technical Support Document; California Environmental Protection Agency, 2007, 55, available at https://ww2.arb.ca.gov/sites/ default/files/barcu/regact/2007/no207/techsupdoc.pdf, accessed in September 2021.

18. Campos, V. P.; Laudo de Rede: Rede de Monitoramento Passivo do Ar na BTS (INCT E\&A), 2016, available at http://www. analisear.com.br/, accessed in September 2021.

19. Yang, Y.; Liu, X.; Zheng, J.; Tan, Q.; Feng, M.; Qu, Y.; An, J.; Cheng, N.; J. Environ. Sci. 2019, 79, 297.

20. Kiesewetter, G.; Borken-Kleefeld, J.; Schöpp, W.; Heyes, C.; Thunis, P.; Bessagnet, B.; Terrenoire, E.; Gsella, A.; Amann, M.; Atmos. Chem. Phys. 2014, 14, 813.

21. Mavroidis, I.; Chaloulakou, A.; Atmos. Environ. 2011, 45, 6872.

22. Querol, X.; Alastuey, A.; Pandolfi, M.; Reche, C.; Pérez, N.; Minguillón, M. C.; Moreno, T.; Viana, M.; Escudero, M.; Orio, A.; Pallarés, M.; Reina, F.; Sci. Total Environ. 2014, 490, 957. 
23. Pérez-Martínez, P. J.; Andrade, M. F.; de Miranda, R. M.; J. Geophys. Res.: Atmos. 2015, 120, 6290.

24. Wild, R. J.; Dubé, W. P.; Aikin, K. C.; Eilerman, S. J.; Neuman, J. A.; Peischl, J.; Ryerson, T. B.; Brown, S. S.; Atmos. Environ. 2017, 148, 182.

25. Casquero-Vera, J. A.; Lyamani, H.; Titos, G.; Borrás, E.; Olmo, F. J.; Alados-Arboledas, L.; Sci. Total Environ. 2019, 646, 1117.

26. Agência Nacional do Petróleo, Gás Natural e Biocombustíveis (ANP); Anuário Estatístico Brasileiro do Petróleo, Gás Natural e Biocombustíveis; ANP: Rio de Janeiro, 2018, available at http://www.anp.gov.br/publicacoes/anuario-estatistico/anuarioestatistico-2018, accessed in September 2021.

27. Nabi, M. N.; Rahman, M. M.; Akhter, M. S.; Appl. Therm. Eng. 2009, 29, 2265.

28. Qi, D. H.; Chen, H.; Geng, L. M.; Bian, Y. Z.; Energy Convers. Manage. 2010, 51, 2985.

29. Lešnik, L.; Vajda, B.; Žunič, Z.; Škerget, L.; Kegl, B.; Appl. Energy 2013, 111, 558.

30. Brazil; Lei No. 8.723, de 28 de outubro de 1993, Dispõe sobre A Redução de Emissão de Poluentes por Veículos Automotores e dá outras Providências; Diário Oficial da União (DOU), Brasília, de 28/10/1993, available at http://www.planalto.gov. br/ccivil_03/leis/18723.htm, accessed in September 2021.

31. Campos, V. P.; Cruz, L. P. S.; Godoi, R. H. M.; Godoi, A. F. L.; Tavares, T. M.; Microchem. J. 2010, 96, 132.

32. SUVK_Senatsverwaltung für Umwelt Verkehr und Klimaschutz; Air Quality Measurement Data Berlin - Annual Report 2018, available at https://www.berlin.de/sen/uvk/umwelt/luft/ luftqualitaet/luftdaten-archiv/\#jahre01-18, accessed in May 2021.

33. Guerranti, C.; Benetti, F.; Cucciniello, R.; Damiani, D.; Perra, G.; Proto, A.; Rossi, F.; Marchettini, N.; Atmos. Pollut. Res. 2016, 7, 754.

34. Proto, A.; Cucciniello, R.; Rossi, F.; Motta, O.; Environ. Sci. Pollut. Res. 2014, 21, 3182.

35. Cucciniello, R.; Proto, A.; Rossi, F.; Motta, O.; Atmos. Environ. 2013, 79, 666.

36. Cucciniello, R.; Proto, A.; Alfano, D.; Motta, O.; Atmos. Environ. 2012, 60, 82.

37. Motta, O.; Cucciniello, R.; la Femina, R.; Pironti, C.; Proto, A.; Talanta 2018, 190, 199.

38. Santana, F. O.; Campos, V. P.; Cruz, L. P. S.; Luz, S. R.; Microchem. J. 2017, 134, 78.

39. Küçükaçıl Artun, G.; Polat, N.; Yay, O. D.; Özden Üzmez, Ö.; Arı, A.; Tuna Tuygun, G.; Elbir, T.; Altuğ, H.; Dumanoğlu, Y.; Döğeroğlu, T.; Dawood, A.; Odabasi, M.; Gaga, E. O.; Atmos. Environ. 2017, 150, 331.

40. Kot-Wasik, A.; Zabiegała, B.; Urbanowicz, M.; Dominiak, E.; Wasik, A.; Namieśnik, J.; Anal. Chim. Acta 2007, 602, 141.

41. Hamilton, R. P.; Heal, M. R.; J. Environ. Monit. 2004, 6, 12.

42. Khuriganova, O. I.; Obolkin, V. A.; Golobokova, L. P.; Bukin, Y. S.; Khodzher, T. V.; Atmosphere 2019, 10, 470.
43. Alfoldy, B.; Mahfouz, M. M. K.; Yigiterhan, O.; Safi, M. A.; Elnaiem, A. E.; Giamberini, S.; Atmos. Pollut. Res. 2019, 10, 445.

44. Kiros, F.; Shakya, K. M.; Rupakheti, M.; Regmi, R. P.; Maharjan, R.; Byanju, R. M.; Naja, M.; Mahata, K.; Kathayat, B.; Peltier, R. E.; Aerosol Air Qual. Res. 2016, 16, 3088.

45. Masey, N.; Gillespie, J.; Heal, M. R.; Hamilton, S.; Beverland, I. J.; Atmos. Environ. 2017, 160, 70.

46. Dahal, B.; Hastings, M. G.; Atmos. Environ. 2016, 143, 60.

47. de Santis, F.; Dogeroglu, T.; Fino, A.; Menichelli, S.; Vazzana, C.; Allegrini, I.; Anal. Bioanal. Chem. 2002, 373, 901.

48. Departamento Nacional de Trânsito (DENATRAN); available at https://www.gov.br/infraestrutura/pt-br/assuntos/transito/ conteudo-denatran/frota-de-veiculos-2019, accessed in September 2021.

49. Alvares, C. A.; Stape, J. L.; Sentelhas, P. C.; de Moraes Gonçalves, J. L.; Sparovek, G.; Meteorol. Z. 2013, 22, 711.

50. Instituto Nacional de Meteorologia (INMET); Station and data; available at https://tempo.inmet.gov.br/TabelaEstacoes/A001, accessed in September 2021.

51. Instituto Brasileiro de Geografia e Estatistica (IBGE); IBGE Divulga as Estimativas da População dos Municípios para 2019, available at https://agenciadenoticias.ibge.gov.br/agenciasala-de-imprensa/2013-agencia-de-noticias/releases/25278ibge-divulga-as-estimativas-da-populacao-dos-municipiospara-2019, accessed in September 2021.

52. EDZA; AnaliseAr, http://www.edza.com.br/produto/analisear, accessed in September 2021.

53. Palmes, E. D.; Lindenboom, R. H.; Anal. Chem. 1979, 51, 2400.

54. Souza, P.; Francisco, K.; Cardoso, A.; Quim. Nova 2017, 40, 1137.

55. NOAA_National Oceanic and Atmospheric Administration; HYSPLIT Trajectory Model, available at https://ready.arl. noaa.gov/hypub-bin/trajtype.pl?runtype=archive, accessed in September 2021.

56. International Union of Pure and Applied Chemistry (IUPAC); Compendium of Chemical Terminology, $2^{\text {nd }}$ ed.; McNaught, A. D.; Wilkinson, A., eds.; 1997.

57. Companhia Ambiental do Estado de São Paulo (CETESB); Qualidade do Ar no Estado de São Paulo, 2017, CETESB: São Paulo, 2017, available at https://cetesb.sp.gov.br/ar/wp-content/ uploads/sites/28/2019/05/Relatório-de-Qualidade-do-Ar-2017. pdf, accessed in September 2021.

58. Instituto Brasileiro do Meio Ambiente e dos Recursos Naturais Renováveis (IBAMA); Programa de Controle de Emissões Veiculares (Proconve), available at https://www.ibama.gov. br/emissoes/veiculos-automotores/programa-de-controle-deemissoes-veiculares-proconve, accessed in September 2021.

59. European Union (EU); Directive Regulation (EC) no 715/2007 on Type Approval of Motor Vehicles with Respect to Emissions from Light Passenger and Commercial Vehicles (Euro 5 and 
Euro 6) and on Access to Vehicle Repair and Maintenance Information; Official Journal of the European Union, 2007, available at https://eur-lex.europa.eu/legal-content/EN/TXT/PD F/?uri=CELEX:32007R0715\&from=PT, accessed in September 2021.

60. European Union (EU); Directive Directive 98/69/EC Relating to Measures to be Taken Against Air Pollution by Emissions from Motor Vehicles and Amending Council Directive 70/220/EEC; Official Journal of the European Union, 1998, available at https:// eur-lex.europa.eu/resource.html?uri=cellar:9ee5d16b-1a4a4a72-ac90-5e3a0bb1d745.0008.02/DOC_1\&format=PDF, accessed in September 2021.

61. Companhia Ambiental do Estado de São Paulo (CETESB); Qualidade do Ar no Estado de São Paulo, 2018, CETESB: São Paulo, 2018, available at https://cetesb.sp.gov.br/ar/wp-content/ uploads/sites/28/2019/07/Relat\%C3\%B3rio-de-Qualidade-doAr-2018.pdf, accessed in September 2021.

62. Portuguese Environmental Agency Air Quality Information (QualAR); National Database on Air Quality in Portugal, available at https://qualar.apambiente.pt/downloads, accessed in September 2021.

63. United States Environmental Protection Agency (EPA); Air Quality Statistics Report, available at https://www.epa.gov/ outdoor-air-quality-data/air-quality-statistics-report, accessed in September 2021.

64. Mozaffar, A.; Zhang, Y. L.; Fan, M.; Cao, F.; Lin, Y. C.; Atmos. Res. 2020, 240, 104923.

65. Karimi, A.; Shirmardi, M.; Hadei, M.; Birgani, Y. T.; Neisi, A.; Takdastan, A.; Goudarzi, G.; Ecotoxicol. Environ. Saf. 2019, $180,542$.

66. Xiao, K.; Wang, Y.; Wu, G.; Fu, B.; Zhu, Y.; Atmosphere 2018 , 9, 74.

67. Barbosa, J. L.: Desenvolvimento de Amostrador Passivo para Óxidos de Nitrogênio (NOx) na Atmosfera; MSc. Dissertation in Chemistry, Universidade Federal da Bahia, Salvador, Brazil, 2017, available at https://repositorio.ufba.br/ri/handle/ri/34243, accessed in September 2021.

68. Manju, A.; Kalaiselvi, K.; Dhananjayan, V.; Palanivel, M.; Banupriya, G. S.; Vidhya, M. H.; Panjakumar, K.; Ravichandran, B.; Air Qual., Atmos. Health 2018, 11, 1179.

69. Vellingiri, K.; Kim, K.-H.; Lim, J.-M.; Lee, J.-H.; Ma, C.-J.; Jeon, B.-H.; Sohn, J.-R.; Kumar, P.; Kang, C.-H.; Atmos. Res. 2016, 176-177, 212.
70. Bigi, A.; Bianchi, F.; de Gennaro, G.; Di Gilio, A.; Fermo, P.; Ghermandi, G.; Prévôt, A. S. H.; Urbani, M.; Valli, G.; Vecchi, R.; Piazzalunga, A.; Atmos. Res. 2017, 186, 83.

71. Agudelo-Castañeda, D. M.; Teixeira, E. C.; Rolim, S. B. A.; Pereira, F. N.; Wiegand, F.; Atmos. Environ. 2013, 70, 254.

72. Cyrys, J.; Eeftens, M.; Heinrich, J.; Ampe, C.; Armengaud, A.; Beelen, R.; Bellander, T.; Beregszaszi, T.; Birk, M.; Cesaroni, G.; Cirach, M.; de Hoogh, K.; de Nazelle, A.; de Vocht, F.; Declercq, C.; Dedele, A.; Dimakopoulou, K.; Eriksen, K.; Galassi, C.; Graulevičiene, R.; Grivas, G.; Gruzieva, O.; Gustafsson, A. H.; Hoffmann, B.; Iakovides, M.; Ineichen, A.; Krämer, U.; Lanki, T.; Lozano, P.; Madsen, C.; Meliefste, K.; Modig, L.; Mölter, A.; Mosler, G.; Nieuwenhuijsen, M.; Nonnemacher, M.; Oldenwening, M.; Peters, A.; Pontet, S.; Probst-Hensch, N.; Quass, U.; Raaschou-Nielsen, O.; Ranzi, A.; Sugiri, D.; Stephanou, E. G.; Taimisto, P.; Tsai, M. Y.; Vaskövi, É.; Villani, S.; Wang, M.; Brunekreef, B.; Hoek, G.; Atmos. Environ. 2012, 62, 374.

73. Zbieranowski, A. L.; Aherne, J.; Atmos. Environ. 2012, 62, 481.

74. Adon, M.; Yoboué, V.; Galy-Lacaux, C.; Liousse, C.; Diop, B.; Doumbia, E. H. T.; Gardrat, E.; Ndiaye, S. A.; Jarnot, C.; Atmos. Environ. 2016, 135, 31.

75. Basagaña, X.; Triguero-Mas, M.; Agis, D.; Pérez, N.; Reche, C.; Alastuey, A.; Querol, X.; Sci. Total Environ. 2018, 610-611, 1076.

76. Schneider, P.; Lahoz, W. A.; van der A. R.; Atmos. Chem. Phys. 2015, 15, 1205.

77. Silvern, R. F.; Jacob, D. J.; Mickley, L. J.; Sulprizio, M. P.; Travis, K. R.; Marais, E. A.; Cohen, R. C.; Laughner, J. L.; Choi, S.; Joiner, J.; Lamsal, L. N.; Atmos. Chem. Phys. 2019, $19,8863$.

78. Alvarez, R.; Weilenmann, M.; Favez, J.-Y.; Atmos. Environ. 2008, 42, 4699.

79. Carslaw, D. C.; Beevers, S. D.; Tate, J. E.; Westmoreland, E. J.; Williams, M. L.; Atmos. Environ. 2011, 45, 7053.

80. Carslaw, D. C.; Beevers, S. D.; Bell, M. C.; Atmos. Environ. 2007, 41, 2073. 